Journal of Physical Science, Vol. 29(Supp. 2), 99-115, 2018

\title{
Seismic Performance of the King Cross Steel Profile in Interior Reinforced Concrete Beam-column Joint
}

\author{
Rahmani Kadarningsih,,${ }^{1,2^{*}}$ Iman Satyarno, ${ }^{1}$ Muslikh $^{1}$ and Andreas Triwiyono ${ }^{1}$ \\ ${ }^{1}$ Department of Civil and Environmental Engineering, Universitas Gadjah Mada, \\ Yogyakarta, 55284 Indonesia \\ ${ }^{2}$ Department of Civil Engineering, Universitas Negeri Gorontalo, \\ Gorontalo, 96128 Indonesia
}

"Corresponding author: rahmanikadarningsih@rocketmail.com

Published online: 30 July 2018

To cite this article: Kadarningsih, R. et al. (2018). Seismic performance of the king cross steel profile in interior reinforced concrete beam-column joint. J. Phys. Sci., 29(Supp. 2), 99-115, https://doi.org/10.21315/jps2018.29.s2.8

To link to this article: https://doi.org/10.21315/jps2018.29.s2.8

\begin{abstract}
The high amount of steel bar reinforcement in beam-column joints causes congestion problem. Here, king cross steel profile, as an alternative to shear reinforcement in the joint of reinforced concrete beam-column, is proposed. This is achieved by simplifying the assembly of king cross steel profile implants at beam-column joints as a shear reinforcement, which could be expected to replace the transversal reinforcement and enhance the joint shear strength. Two sets of interior beam-column joint subassemblies with stirrup reinforcement (SJ) and with king cross steel profile reinforcement (KCJ) as the shear reinforcement in the joint were studied. The experimental result concluded that the average peak load of SJ specimen was higher than that of KCJ. However, KCJ had good performance and contributed to the shear strength of the joint. The performance and contribution of KCJ can be seen from the load carrying capacity above $6.7 \%$ in the positive direction and below $24.91 \%$ in the negative direction compared with SJ. The pattern of the crack occurred showed a severe failure in the joint panel of KCJ. In this study, the width of the web was twice that of the flange, but in future studies, the width should be enlarged until it sufficiently fills the entire joint section and the width of the web is about six times of the flange. This web enlargement and flange reduction were performed by considering the area of a cross-section of the king cross profile and the requirement of shear capacity of the joint installed. It was done to increase the shear strength of the interior beam-column joint subassemblies with KCJ.
\end{abstract}

Keywords: King cross steel profile, shear reinforcement, beam-column joint shear strength, interior beam-column joint, joint shear failure 


\section{INTRODUCTION}

The beam column joint (BCJ) is a crucial area where the transfer of loads from the beams to columns occurs. Seismic load causes a great shear force at the joints. This behaviour is very different when compared with the behaviour of joints due to gravity loads. The beams assembled at the joint resist the moment in the same direction due to seismic load, thus increasing the shear force in the joint. Therefore, the design capacity of the joint must be strong enough to ensure that the adjoining members achieve plastic deformation. In the interior joint, the action occurs in both directions, hence requiring a complex design.

The shear forces occurring at joints are resisted by the joint stirrup, together with the concrete through the truss and the strut mechanism in the design of the conventional BCJ. The failure of the joint should be avoided but to achieve this, the requirements for the joint shear stirrups are sometimes challenging. The demanding requirements cause the space of the stirrups so dense making it lower than the minimum allowable distance between reinforcement. The space between the densed reinforcement bars will cause incomplete consolidation, increased permeability and reduction of concrete strength. ${ }^{1}$

Chen and Lin experimented on the steel reinforced concrete (SRC) beam-column joint. ${ }^{2}$ The SRC beam-column joint is composed of concrete, a cross-sectional steel shape, longitudinal steel bar and transverse steel bar. A cross-sectional steel shape henceforth has been named king cross profile. Chen and Lin observed that the use of king cross steel profiles on reinforced concrete columns can enhance the shear capacity of the BCJ $40 \%$ higher than the use of $\mathrm{H}$ steel profiles. ${ }^{2}$ The use of king cross profile is expected to be able to reduce the use of joint stirrup to solve the congestion problem in the joint.

The king cross steel profiles can increase the shear capacity without enhancing the number of stirrups to avoid joint failure and ensure a strong column beam mechanism. The joint shear capacity is expected to reach the inelastic capacity of flexural beam and the mechanism of plastic deformation in design can be developed and maintained..$^{3,4}$ 


\section{EXPERIMENTAL}

\subsection{Material Properties}

The BCJ specimen has a compressive concrete strength of $40.6 \mathrm{MPa}$. The concrete mix consists of Portland composite cement (PCC), sand and the crushed stone of aggregated size passing through $10 \mathrm{~mm}$. The reinforcement properties used on both specimen are similar except for the material on joint reinforcement as shown in Table 1.

Table 1: Reinforcement properties of BCJ specimen.

\begin{tabular}{lccc}
\hline Details and material properties & & Values & Values \\
\hline \multirow{2}{*}{ Beam longitudinal bar } & Ratio (\%) & 2.342 & 2.342 \\
& $\mathrm{f}_{\mathrm{y}}(\mathrm{MPa})$ & 423.68 & 423.68 \\
Column longitudinal bar & Ratio $(\%)$ & 1.787 & 1.787 \\
Transverse reinforcement & $\mathrm{f}_{\mathrm{y}}(\mathrm{MPa})$ & 393.19 & 393.19 \\
Concrete compressive strength & $\mathrm{f}_{\mathrm{y}}(\mathrm{MPa})$ & 373.72 & 373.72 \\
Joint transverse reinforcement & $\mathrm{f}^{\prime} \mathrm{c}(\mathrm{MPa})$ & 40.6 & 40.6 \\
& $\mathrm{f}_{\mathrm{y}}(\mathrm{MPa})$ & 387.9 & - \\
King cross steel profile & $\mathrm{f}_{\mathrm{yf}}(\mathrm{MPa})$ & 2 & 257.39 \\
& $\mathrm{f}_{\mathrm{yw}}(\mathrm{MPa})$ & 1.4 & 207.39 \\
\hline
\end{tabular}

\subsection{Description of Test Specimens}

Two sets of interior BCJ subassemblies were prepared for testing. Specimens were designed to the concept of failure at the joint to measure the strength of the joint. The joint of control specimen was designed base on Park and Paulay and the joint of king cross steel profile was designed base on Chen and Lin., ${ }^{2,5}$ The joint shear demand was used to design the specimen joint. The joint shear demand is:

$$
V_{u}=T_{S}+C_{S}-V_{C}
$$

where $V_{u}$ refers to joint shear demand $(\mathrm{kN}), T_{s}$ is the beam tensile force calculated from the beam tensile bar $(\mathrm{kN}), C s$ is the beam compression force calculated from the beam compression bar $(\mathrm{kN})$, and $V_{c}$ refers to column shear $(\mathrm{kN})$. The shear capacity design of joint reinforcement $\left(V_{j h}\right)$ was calculated by subtracting the joint shear demand $\left(V_{u}\right)$ from the concrete shear capacity of joint $\left(V_{c r}\right)$. The concrete shear capacity of joint $\left(V_{c r}\right)$ and the shear capacity design of joint reinforcement $\left(V_{j h}\right)$ ware calculated using the following equation: 


$$
V_{c r}=0.29 \sqrt{f^{\prime} c} \sqrt{\left(1+0.29 N_{u} / A_{g}\right)}
$$

and

$$
V_{j h}=V_{u}-V_{c r}
$$

The installed joint shear capacity $\left(V_{n}\right)$ was only less than half of the joint shear demand to achieve the joint shear failure Equation 4. Therefore, the joint shear strength be measured.

$$
V_{n}=0.25 V_{j h}
$$

The joint shear demand calculation obtained $V_{u}=581.599 \mathrm{kN}$ (as shown in Table 2) and then the installed joint shear capacity was taken as $V_{j h}=372.106 \mathrm{kN}$ (Table 2). If the joint reinforcement was stirrup or king cross profile then the shear capacity of stirrup and king cross profile taken as $V_{s}=V_{n}=93.03 \mathrm{kN}$ and $V_{s w}+V_{s f}=V_{n}$ $=93.03 \mathrm{kN}$. Table 2 presents the calculation of the shear capacity of the installed

\begin{tabular}{|c|c|}
\hline $\begin{array}{l}\text { Stages of the nominal of the shear } \\
\text { capacity of the installed joint }\end{array}$ & The calculation \\
\hline \multirow{4}{*}{ Beam moment design $\left(M_{p r b}\right)$} & $M_{p r, b 1}=A_{S 1} \alpha f_{y}(d-a / 2)$ \\
\hline & $=51.15 \mathrm{kNm}$ \\
\hline & $M_{p r, b 2}=A_{S 2} \alpha f_{y}(d-a / 2)$ \\
\hline & $=86.7 \mathrm{kNm}$ \\
\hline \multirow{3}{*}{ Column shear force $\left(V_{c}\right)$} & $V_{c}=V_{c 1}+V_{c 2}$ \\
\hline & $=\left(M_{p r b 1}+M_{p r b 2}\right)\left(1 / l_{c}+h_{c} / 2 l_{b} l_{c}\right)$ \\
\hline & $=51.005 \mathrm{kN}$ \\
\hline \multirow{4}{*}{$\begin{array}{l}\text { Beam tension }\left(T_{s}\right) \text { and compression } \\
\text { force }\left(C_{s}\right)\end{array}$} & $T_{s}=\alpha f_{y} A_{S 1}$ \\
\hline & $=210.89 \mathrm{kN}$ \\
\hline & $C_{s}=\alpha f_{y} A_{S 1}$ \\
\hline & $=421.77 \mathrm{kN}$ \\
\hline
\end{tabular}
joint.

Table 2: The calculation of the shear capacity of the installed joint. 
Table 2: (continued)

\begin{tabular}{|c|c|}
\hline $\begin{array}{l}\text { Stages of the nominal of the shear } \\
\text { capacity of the installed joint }\end{array}$ & The calculation \\
\hline The shear force design of joint $\left(V_{u}\right)$ & $\begin{aligned} V_{u} & =T_{S}+C_{S}-V_{C} \\
& =581.599 \mathrm{kN} \mathrm{V}\end{aligned}$ \\
\hline The concrete shear capacity of joint & $\begin{aligned} V_{c r} & =0.29 \sqrt{f_{c}^{\prime}} \sqrt{\left(1+0.29 N_{u} / A_{g}\right)} \\
& =209.49 \mathrm{kN}\end{aligned}$ \\
\hline $\begin{array}{l}\text { The shear capacity design of joint } \\
\text { reinforcement }\left(V_{j h}\right)\end{array}$ & $\begin{aligned} V_{j h} & =V_{u}=V_{c r} \\
& =372.106 \mathrm{kN}\end{aligned}$ \\
\hline $\begin{array}{l}\text { The installed joint shear capacity } \\
\left(V_{n}\right)\end{array}$ & $\begin{aligned} V_{n} & =0.25 V_{j h} \\
& =93.03 \mathrm{kN}\end{aligned}$ \\
\hline
\end{tabular}

The stirrup of specimen control is calculated by the following equation:

$$
A_{v}=v_{S} S b_{w} / f_{y}
$$

and

$$
A_{v}=\left(v_{S} S\right) /\left(\left(d-d^{\prime}\right) f_{y}\right)
$$

where $V_{s}=V_{n}$ refers to shear capacity of stirrup $(\mathrm{kN}), s$ represents a space distance between stirrup (mm), $b_{w}$ is the depth of stirrup $(\mathrm{mm}), f_{y}$ is the yield strength of stirrup (MPa), $A_{s}$ is the cross-section area of stirrup $\left(\mathrm{mm}^{2}\right)$, and $d-d$ ' refers to the distance between the centroid of the top and bottom beam bar ( $\mathrm{mm})$.

The joint of king cross profile reinforcement $(\mathrm{KCJ})$ to resist the shear force and was calculated through the following equation:

$$
V_{s w}=f_{y w} H_{t 1}
$$

and

$$
V_{s f}=2 f_{y f} B t_{2}
$$


where $V_{s w}$ is the shear capacity of web of $\mathrm{KCJ}(\mathrm{kN}), f_{y w}$ is the yield strength of web (MPa), $H$ is the depth of web $(\mathrm{mm}), t_{l}$ denotes the thick of web $(\mathrm{mm}), f_{y f}$ is the yield strength of flange (MPa), $B$ is the depth of flange $(\mathrm{mm}), t_{2}$ is the thickness of flange $(\mathrm{mm})$, and the dimensional details of king cross profile are presented in Figure 1 .

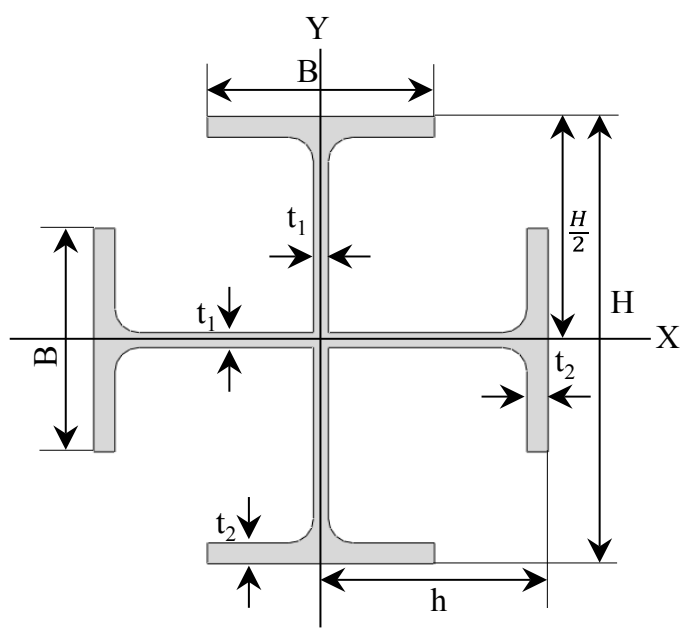

Figure 1: The dimensional details of king cross profile.

The stirrup of joint and the king cross profile of joint design calculation is presented in Table 3.

Beam-column joint subassemblies were designed as beam column specimen with a stirrup reinforcement (SJ) and beam-column specimen with KCJ in the joint, respectively. The descriptions of the specimens are presented in Table 3 and the dimensional details of test specimen are presented in Figures 2 and 3. 
Table 3: Joint design calculation.

\begin{tabular}{|c|c|c|c|}
\hline $\begin{array}{l}\text { Shear capacity of } \\
\text { stirrup }\left(V_{s}\right)\end{array}$ & $\begin{array}{l}\text { Detail of stirrup } \\
\text { of joint }\end{array}$ & $\begin{array}{l}\text { Shear capacity of } \\
\text { king cross }\end{array}$ & $\begin{array}{l}\text { Detail of joint } \\
\text { king cross }\end{array}$ \\
\hline $\begin{aligned} V_{s} & =V_{n} \\
& =93.03 \mathrm{kN}\end{aligned}$ & $\begin{array}{l}\begin{array}{l}v_{s}=V_{s} /(b d) \\
\quad=1.03 \mathrm{Nmm}^{-2}\end{array} \\
\text { use the diameter of } \\
\text { the stirrup is } 6 \mathrm{~mm} \\
s=\left(A_{v} f_{y}\right) /\left(v_{s} b_{w}\right) \\
=70.74 \mathrm{~mm} \\
\text { use } \phi 6 / 66\end{array}$ & $\begin{aligned} V_{s w}+V_{s f} & =V_{n} \\
& =93.03 \mathrm{kN}\end{aligned}$ & 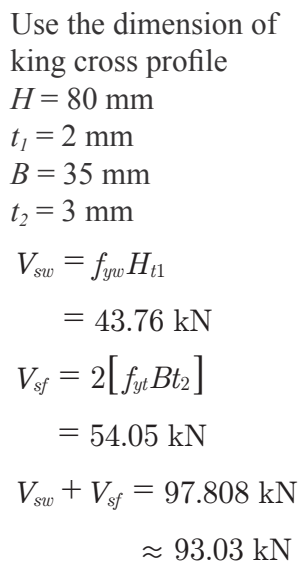 \\
\hline
\end{tabular}

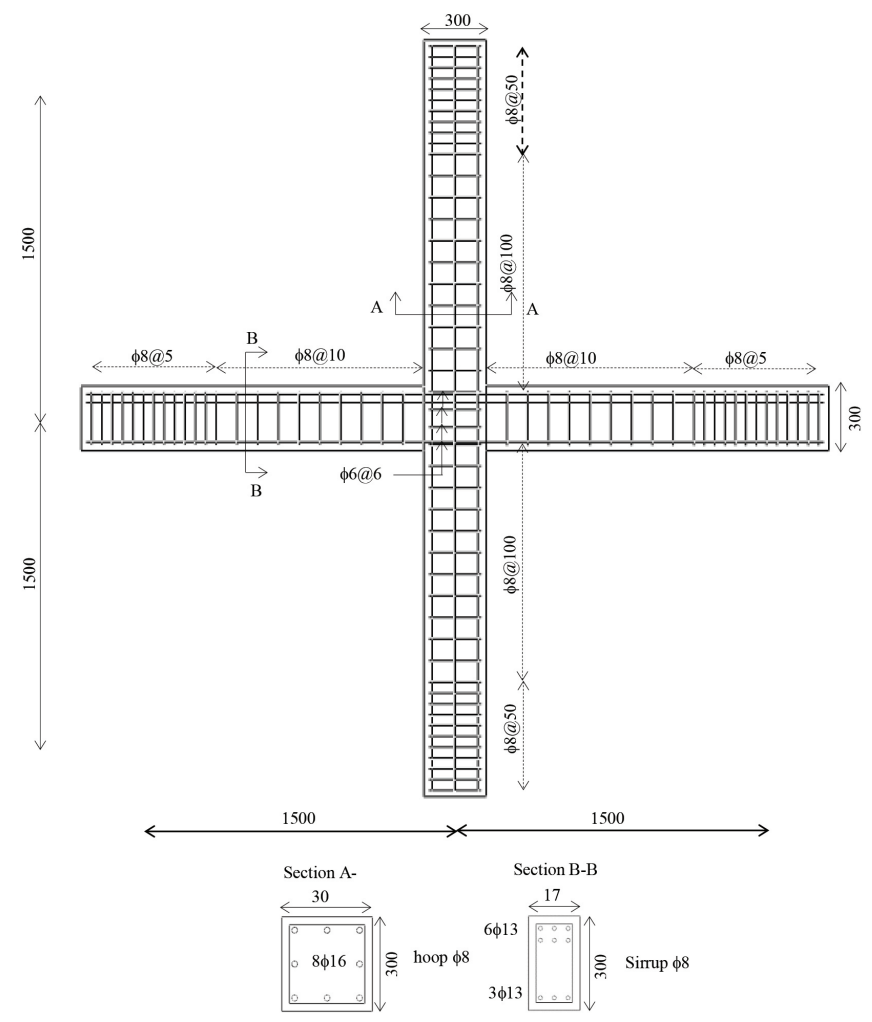

Figure 2: Dimensional details of beam-column joint with SJ. 


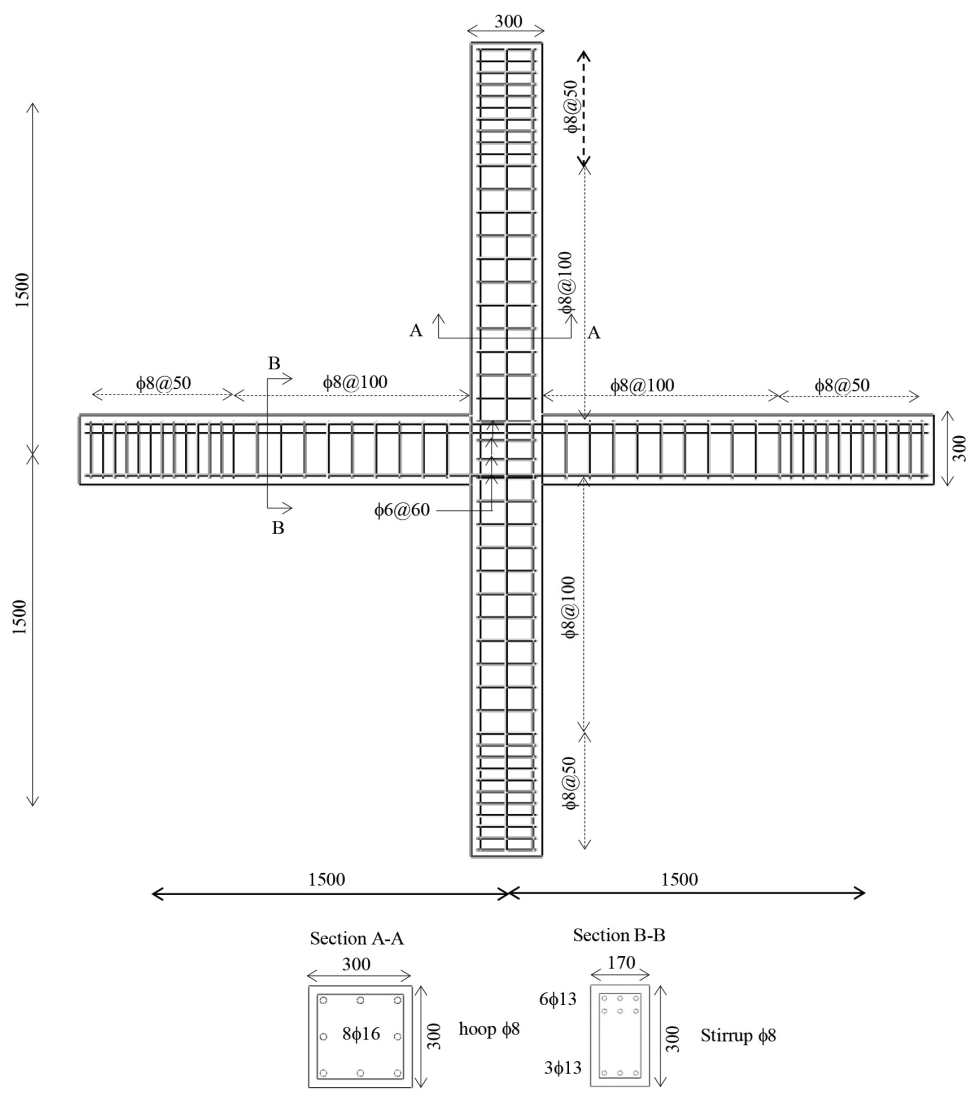

Figure 3: Dimensional details of beam-column joint with king cross profile.

\subsection{Test Set Up and Procedures}

The schematic representation of the test set up is shown in Figure 4, similar to report by Wijaya. ${ }^{12}$ The specimens were placed in horizontal position on the surface of the rigid floor. The axial load was imposed at the end of the column above by using a hydraulic jack. The axial load magnitude was constantly kept at $180 \mathrm{kN}$ during the test. It was less than $a f^{\prime}{ }_{c} A_{g}$, where $f_{c}$ is concrete compressive strength of $35 \mathrm{MPa}, A_{g}$ refers to the gross area of the column $\left(90000 \mathrm{~mm}^{2}\right)$ and $\alpha=0.1$ because the concrete shear capacity of joint has been calculated using Equation 2, not using the equation based on SK SNI-T-15-1991-03 as follows. ${ }^{6}$

$$
V_{c h}=2 / 3 \sqrt{N_{u} / A_{g}-0,1 f_{c}^{\prime} b_{j} h_{c}}
$$




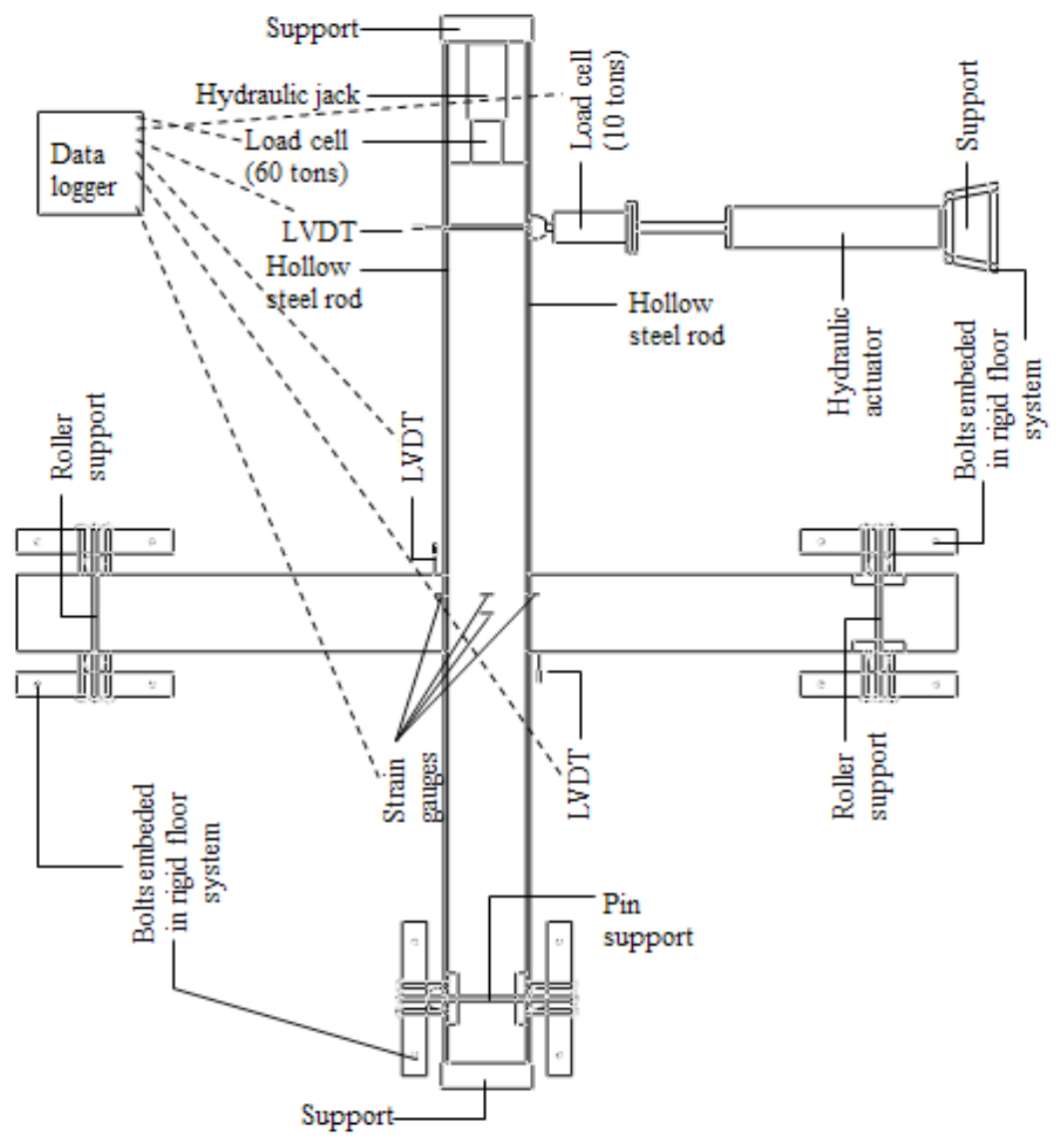

Figure 4: Schematic arrangement of cyclic test set up. ${ }^{12}$

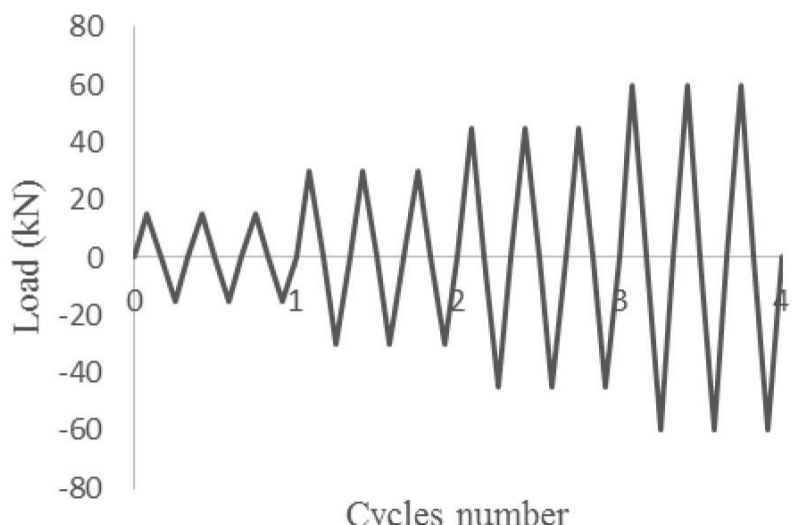

Figure 5: Load sequence diagram. 
The concrete shear capacity of joint $\left(V_{c r}\right)$ based on Park and Paulay considered the small axial load on the column compared to the Indonesia National Standard for concrete building with code number SNI 03-2847-1992..$^{5}$ The hydraulic actuator capacity $100 \mathrm{kN}$ was used for applying the cyclic lateral load at near end of the same column. The displacement imposed was recorded by linear variable differential transformer (LVDT) at a point on the side of the near end of the column. The magnitude of reversed lateral load was recorded at several cyclic loading stages as shown in Figure 5. The loading based on the force control cycle was carried out in several studies including by Marsono and Hatami, Rajaram et al., and Rajagopal and Prabavathy. ${ }^{7-9}$ Based on Federal Emergency Management Agency (FEMA) standard for determining the seismic performence characteristic of structural and nonstructural component with code number FEMA 461/2007, the force or displacement-controlled testing can be performed to control the performance of the component. Conceptually, the force loading history of the experiment does not conform to FEMA 461/2007, because the number of steps or increments in the loading history in FEMA 461/2007 are generally 10 or larger. Therefore, the cyclic loading stages in Figure 5 cannot precisely and accurately reflect the loop hysteretic curve, but they can still describe the behaviour of the two specimens. ${ }^{10}$

The pinned support located at the end of the bottom column and at both ends of the beams are the roller support. The setting of the pin support has been used in the study by Makmur and Wijaya, respectively. ${ }^{11,12}$ However, it turned out in that in this study that the support arrangement could not function as a perfect pinned support. At $8 \%$ drift loading, there was a downward vertical movement on the bottom end of the column. ${ }^{11,12}$

\section{EXPERIMENTAL}

\subsection{Crack Formation and Failure Mode}

The typical crack pattern of control specimens SJ and KCJ was presented in Figures 6 and 7. In control specimens, the first visible crack appeared at the joint. Beam-column joint remained undamaged at low displacement level. With the increase in displacement level, diagonal tension crack appeared at the joint panel. This was followed by the crack formation in beam close to column interface with the increase in displacement. The failure mechanism was a mixing mechanism in which diagonal cracking in the joint panel was accompanied by a flexural damage in the beam. The yielding of stirrup reinforcement in joint occurred before yielding of steel reinforcement bar in the beam. 


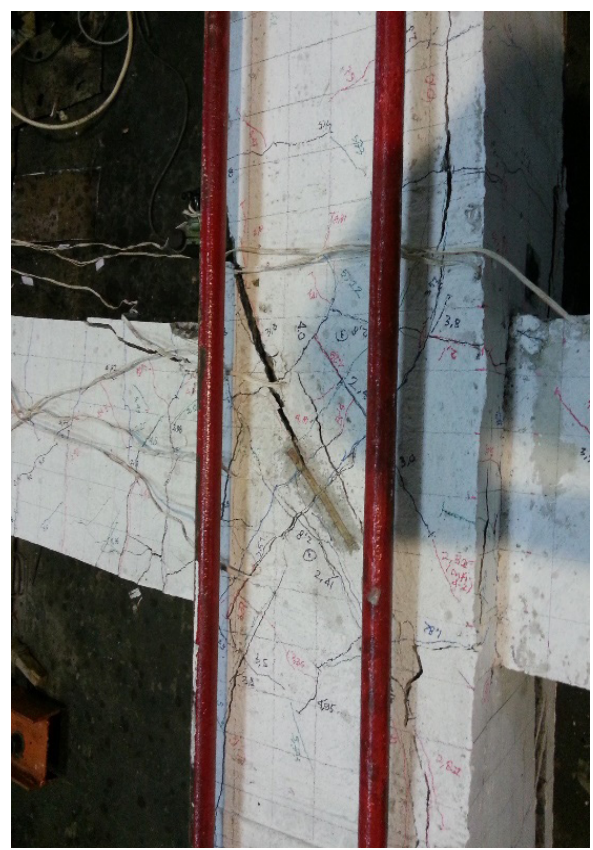

Figure 6: Crack pattern in control specimen SJ.

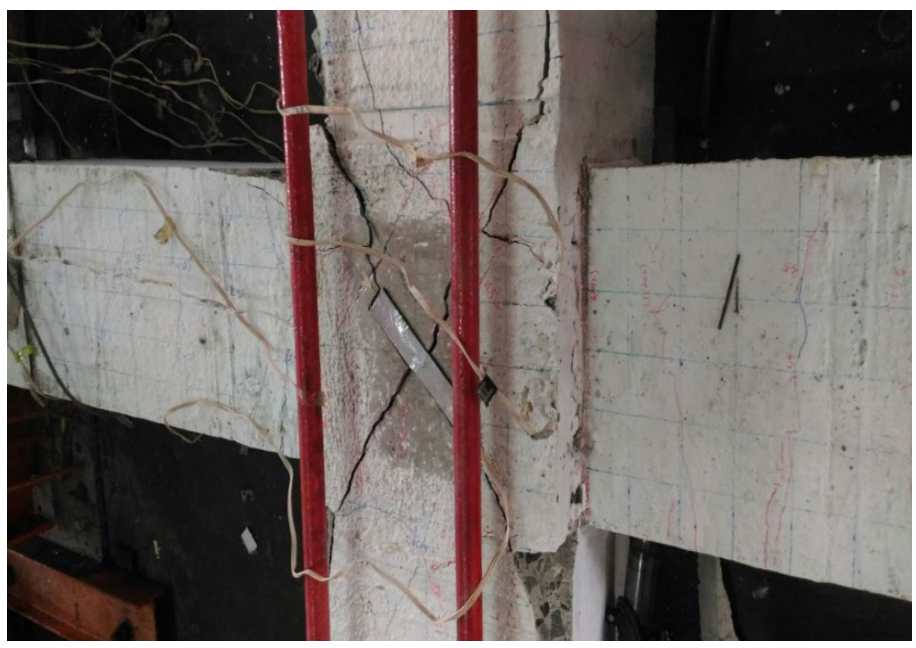

Figure 7: Crack pattern in specimens with KCJ.

\subsection{Hysteretic Response and Load Carrying Capacity}

Load-displacement hysteretic curves of both specimen tests are presented in Figures 8 and 9. From the shape of the hysteretic loop, it could be observed that SJ and KCJ 
had pinching. The pinching illustrates that the mechanism of plastification of both specimens is unstable. Specimens SJ and KCJ suffered from the shear damage in the joint panel, hence no energy was dissipated. This has caused the form of hysteretic loops on both specimens to be pinched. On non-pinched specimens, the plastification mechanism is more stable. The mechanism of plastification on non-pinched specimen occurs by forming a plastic hinge and bending failure on the beam. ${ }^{13}$

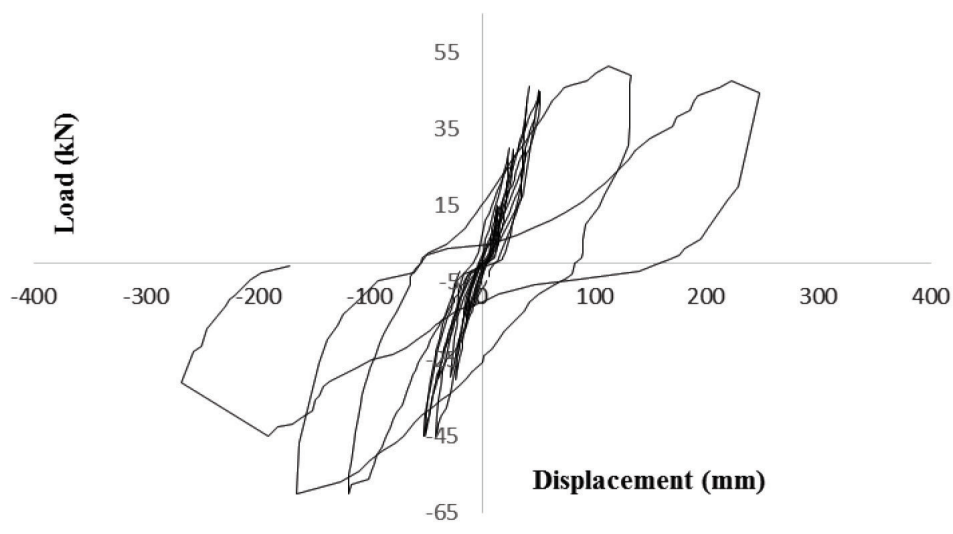

Figure 8: Hysteretic curve for SJ.

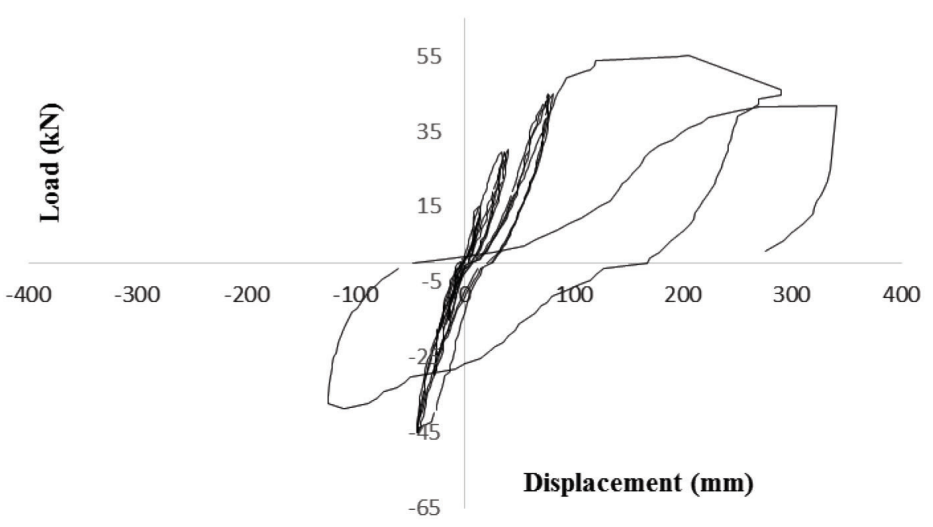

Figure 9: Hysteretic curve for KCJ. 
Table 4: Peak load of test specimen under cyclic loading.

\begin{tabular}{lcccc}
\hline & \multicolumn{2}{c}{ SJ } & \multicolumn{2}{c}{ KCJ } \\
\cline { 2 - 5 } & Load $(\mathrm{kN})$ & Displacement $(\mathrm{mm})$ & Load $(\mathrm{kN})$ & Displacement $(\mathrm{mm})$ \\
\hline Positive peak load & 51.5 & 112.49 & 55.2 & 205 \\
Negative peak load & -60.2 & 166 & -45.5 & 42 \\
\hline
\end{tabular}

To obtain the peak loads of the test specimen, the envelop curve was drawn by connecting the peak loads at each displacement level in both positive and negative direction. Typical failure envelope of the specimen is presented in Figure 10. Peak load of all the specimens is presented in Table 3. It was observed that the peak load of SJ was higher than that of KCJ. However, the failure of the specimen on the loop hysterical curve could not be excellently represented, especially on the negative load. This occurs because the use of cyclic loading stage (Figure 5) did not conform to FEMA 461/2007 on the conceptual approaches for the development of force controlled loading history.

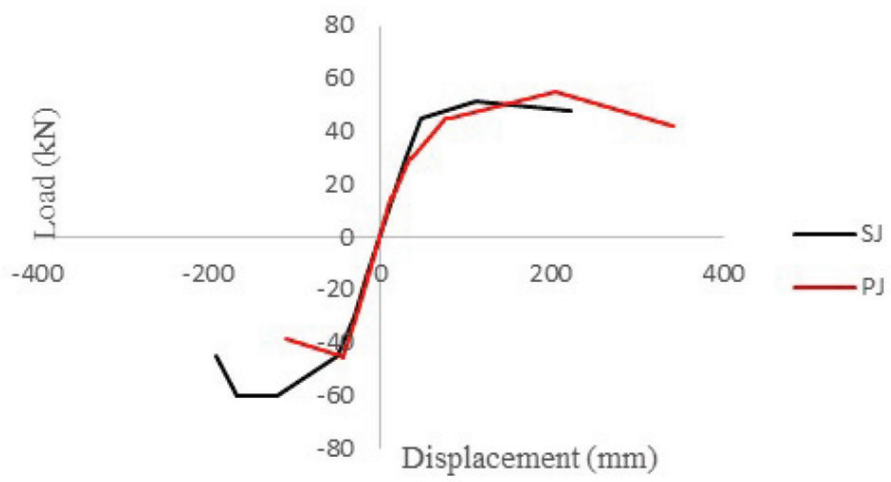

Figure 10: Failure envelope SJ and PJ. 


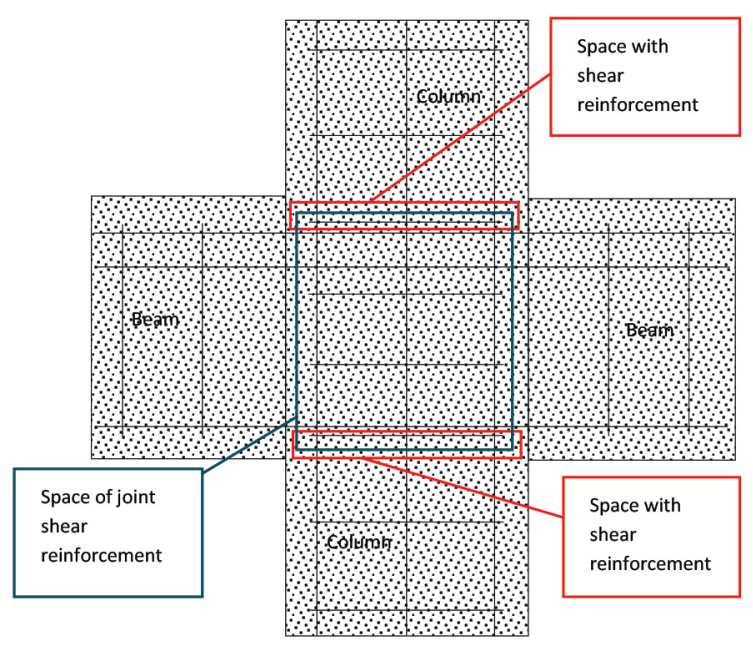

Figure 11: Space of joint shear reinforcement of SJ

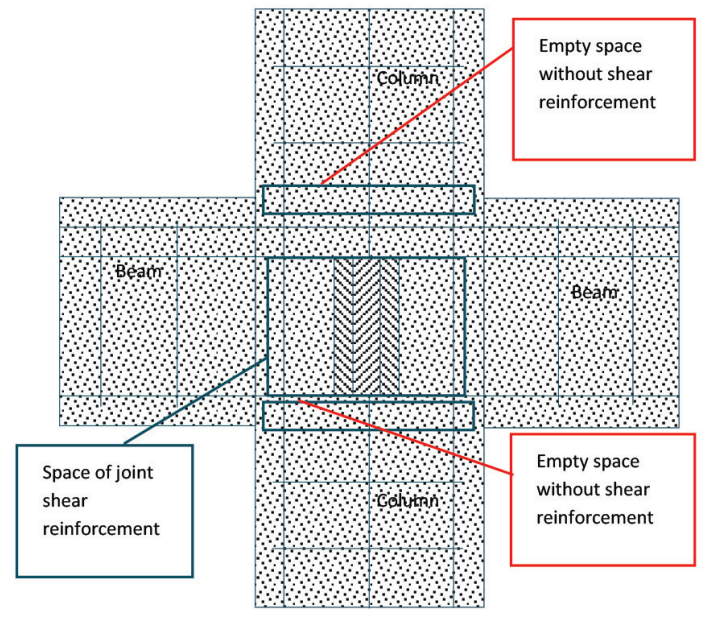

Figure 12: Space of joint shear reinforcement of KCJ.

The second reason the peak load of SJ specimen was higher than KCJ was that the section of king cross steel profile used was too small, hence it is not sufficient to fill the entire section, as shown in Figure13(a). Thus, the section of king cross was enlarged and fixed as shown in Figure 13(b). 


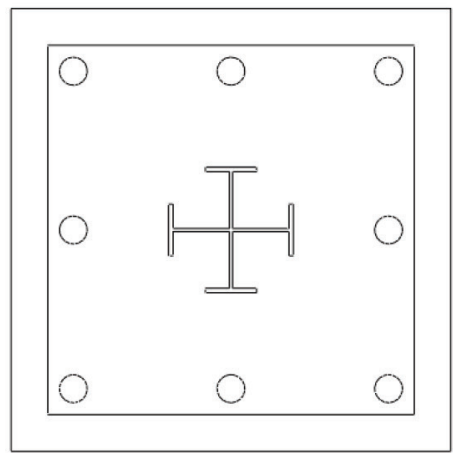

(a)

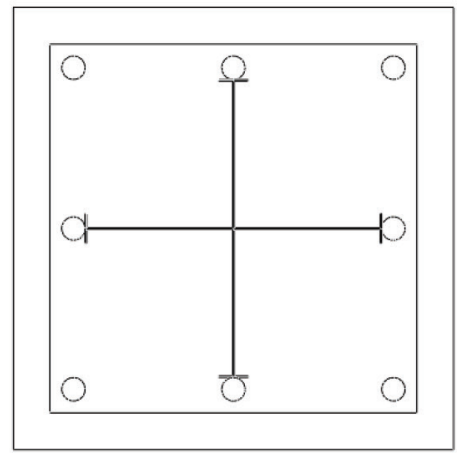

(b)

Figure 13: Illustrations of (a) the sufficient of king cross profile, and (b) the enlarged of king cross profile with the same of nominal area.

\section{CONCLUSION}

In the beam-column joint with $\mathrm{KCJ}$, the first crack was observed in the joint panel. It was found that the number of beam cracks in the specimen with king cross steel profile in the joint was fewer than the ones in control specimen SJ. It was also observed that the joint was damaged earlier compared with the beam. This was different from SJ where the joint failure was almost simultaneous or followed by beam damage. Hence, it can be concluded that the joint strength of BCJ control is still higher than the $\mathrm{BCJ}$ with king cross steel.

The load-displacement hysteretic curves for both specimen tests are presented in Figures 6 and 7. From the shape of the hysteretic loop, it can be observed that SJ and KCJ have pinching. The pinching illustrates that the mechanism of plastification of both specimens is unstable. Specimens SJ and KCJ suffered from shear damage in the joint panel rather than no energy to be dissipated.

The peak load of SJ specimen was higher than KCJ. This condition was caused by several factors. Firstly, as presented in Figures 11 and 12, the king cross steel only resisted the shear in the joint space between the top and the bottom of the longitudinal bar while the space above was left without any reinforcement or being empty. This was different from the SJ specimen. Secondly, the section of king cross steel used was so small so that it was not sufficient to fill the entire section. For this, the section of king cross should be enlarged. 
$\mathrm{KCJ}$ has good performance and contributes to the shear strength of the joint. This can be seen from the load carrying capacity of KCJ specimens at $50.35 \mathrm{kN}, 10 \%$ below the load carrying capacity of SJ specimens. On the other hand, the pattern of the crack occurred showed a severe failure in the joint panel of KCJ specimen compared with SJ.

\section{ACKNOWLEDGEMENTS}

The authors gratefully acknowledge the funding provided by Directorate General of Research and Development, Ministry of Research, Technology and Higher Education, Republic Indonesia through Doctoral Dissertation Research Fiscal Year 2017 grant number 484/UN47.D/PL/2017.

\section{REFERENCES}

1. ACI 309 3R-92. (1992). Guide to consolidation of concrete in congested areas. Farmingham Hils, MI: American Concrete Institute.

2. Chen, C. C. \& Lin, K.T. (2009). Behavior and strength of steel reinforced concrete beam-column joints with two-side force inputs. J. Constr. Steel Res., 65, 641-649.

3. Kadarningsih, R. et al. (2014). Proposals of beam column joint reinforcement in reinforcement in reinforced concrete moment resisting frame: A literature review study. Proced. Eng., 95, 158-171.

4. Kadarningsih, R. et al. (2017). Analysis and design of reinforced concrete beam column joint using king cross steel profile. Proced. Eng., 171, 948956.

5. Park, R. \& Paulay, T. (1975). Reinforced concrete structures. Wellington: John Wiley.

6. SK SNI T-15-1991-03. (1991). Tata cara perhitungan struktur beton untuk bangunan gedung. Unpublished paper, Departemen Pekerjaan Umum, Yayasan LPMB, Bandung, Indonesia.

7. Marsono, A. \& Hatami, S. (2015). Evaluation of coupling beam behavior concrete shear wall with rectangular and octagonal openings. Appl. Mech. Mater., 735, 104-108.

8. Rajaram, P., Murugesan, A. \& Thirugnanam, G. S. (2010). Experimental study on behavior of interior RC beam column joints subjected to cyclic loading. Int. J. Appl. Eng. Res., 1(1), 49-59. 
9. Rajagopal, S. \& Prabavathy, S. (2015). Investigation on seismic behavior of exterior beam column joint using T-type mechanical anchorage with hair clip bar. J. King Saud Uni. Eng. Sci., 27(2), 142-152.

10. FEMA 461 (2007). Interim testing protocols for determining the seismic performance characteristics of structural and nonstructural components. Redwood City: Applied Technology Council.

11. Makmur, M. (2015). Perilaku sambungan balok kolom pracetak interior untuk bangunan sederhana berdasarkan metode eksperimen. Master diss., Universitas Gadjah Mada, Indonesia.

12. Wijaya, M. (2015). Retrofitting of reinforced concrete interior beam column joint using polyester resin concrete. Masters diss., Universitas Gadjah Mada, Indonesia.

13. Roy, B. \& Laskar, A. I. (2017). Cyclic behavior of in situ exterior beam column subassemblies with cold joint column. Eng. Struct., 132, 822-833. 